\author{
Arkadiusz Badziński \\ Uniwersytet Śląski \\ arkadiusz.badzinski@us.edu.pl
}

\title{
DYSKURS W DOMENIE JĘZYKA SPECJALISTYCZNEGO MEDYCZNEGO - UWAGI DLA TŁUMACZY I DYDAKTYKÓW PRZEKŁADU
}

DOI: http://dx.doi.org/10.12775/RP.2019.020

Zarys treści: Dyskurs medyczny i jego analiza pozostają kwestiami problematycznymi z powodu mnogości definicji pojęć oraz różnej metodologii badań. Skuteczna komunikacja na różnych płaszczyznach pozostaje warunkiem sine qua non przekazu zgodnego z zasadami medycyny opartej na dowodach. Artykuł - w formie praktycznych uwag dla tłumaczy, którym zawsze powinna przyświecać maksyma primum non nocere - szczegółowo omawia dyskurs oraz język specjalistyczny medyczny, z uwzględnieniem w dydaktyce przekładu problematyki kolokacji, precyzji, metonimii i metafory w wysokospecjalistycznym dyskursie medycznym, charakteryzującym się mnogością specjalizacji oraz proliferacją terminologiczną.

Słowa kluczowe: dyskurs medyczny, język medyczny, kolokacje medyczne, przekład medyczny, dydaktyka języka medycznego

\section{Wprowadzenie}

Dojęcie języka medycznego jest bezpośrednio związane z pojęciem komunikacji. Kontakt z medycyną wiąże się z przekazem danej informacji lub tekstu, który Duszak (1998) kategoryzuje jako zdarzenie komunikacyjne. Tekst jest więc rozpatrywany w kontekście danej sytuacji komunikacyjnej oraz jest jednym ze składowych aktu komunikacji, który w domenie lingwistyki tekstu określany jest mianem dyskursu (tamże). Zjawisko to jest więc kwe- 
stią kluczową w komunikacji, a także w tłumaczeniach zarówno pisemnych, jak i ustnych (symultanicznych oraz konsekutywnych). Nieznajomość reguł z nim związanych może utrudniać lub nawet uniemożliwiać prawidłowy przekaz informacji czy też przekład specjalistyczny. W związku z powyższym temat dyskursu, a także zjawisk z nim związanych ma kluczowe znaczenie zarówno dla tłumacza, procesu przekładu specjalistycznego, jak i dla dydaktyki języka specjalistycznego, która powinna wychodzić naprzeciw trudnościom oraz zapotrzebowaniu rynku na tego typu usługi.

\section{Dyskurs, jego analiza oraz wspólnota dyskursu}

Pojęcie dyskursu (łac. discurrere - dosł. 'poruszanie się) używane jest w wielu dyscyplinach czy specjalizacjach, a medycyna nie jest tutaj wyjątkiem. Mnogość interpretacji tego słowa pozwoliła na dość swobodne jego użycie w różnych domenach (zarówno naukowych, jak i popularnonaukowych), czyniąc $\mathrm{z}$ niego termin bardzo modny oraz pojęcie wysoce elastyczne do tego stopnia, że Jerzy Szacki (2005: 905) słusznie zauważa, iż „słowo dyskurs zrobiło [już tak] oszałamiającą karierę (...), [że] coraz trudniej o pewność, czy w ogóle jeszcze cokolwiek znaczy, [ponieważ używa się go na] wiele różnych sposobów [często] jako (...) określenia (...) dowolnego tekstu”. Uwaga ta w żadnym stopniu nie powinna jednak zniechęcać do głębszej analizy omawianego zjawiska. Wprost przeciwnie, może raczej stanowić przyczynek do poszerzenia badań nad niniejszym zjawiskiem oraz językiem specjalistycznym w domenie, jaką jest medycyna.

Omawiając zjawisko dyskursu, należy mieć na uwadze fakt, że początkowo istniały znaczące rozbieżności między polskim a angielskim rozumieniem terminu, jakim jest dyskurs, który pojawiał się jako „bliżej nieokreślone pojęcie komunikacji językowej” (Duszak 1998: 14). Z czasem jednak różnice te stały się znacznie mniejsze, prawdopodobnie z uwagi na pozycję języka angielskiego jako lingua franca, a co za tym idzie, wszechobecnym wpływem na pozostałe języki, w tym na język polski (por. Noińska 2017). Jak słusznie zauważa Marta Noińska (2017: 108), użycie pojęcia dyskurs „ma nieco odmienną tradycję zarówno w różnych dziedzinach nauki, jak i w poszczególnych językach", co skutkuje wewnątrz- oraz międzyjęzykową wieloznacznością terminu, po części uwarunkowaną progresją zmian związanych $\mathrm{z}$ interdyscyplinarnością dziedzin, dyscyplin czy wreszcie badan. Wobec powyższego dyskurs pozostaje pojęciem niejednoznacznym, niezależnie od tego, czy jest rozpatrywany z perspektywy języka ogólnego, czy też specjalistycznego, 
co podkreśla m.in. van Dijk (2001: 9). Różne sposoby rozumienia pojęcia prezentowali na przykład Maria Wojtak (2010) i Elżbieta Laskowska (2004). Noińska (2017: 101, za: Kiklewicz 2015) zauważa, że taka sytuacja uwarunkowana jest ambisemią, rozumianą jako reinterpretacja „kategorii pojęciowych przez badaczy należących do odmiennych formacji naukowych, preferujących odmienne systemy konceptualizacji rzeczywistości".

W niniejszym artykule dyskurs $\mathrm{w}$ aspekcie medycznym określa wydarzenie komunikacyjne/interakcję komunikacyjną z udziałem specjalistów, którzy są członkami wspólnoty dyskursu. Wydarzenie to złożone jest $\mathrm{z}$ trzech komponentów, jakimi są: użycie języka, następnie przekazanie idei oraz interakcja w kontekście społecznym (por. van Dijk 2001: 10). Dyskurs jest jednostką językową obejmującą formy języka zarówno mówionego, jak i pisanego (Bachtin 1986; Ballard 2016). Co istotne, wspólnota dyskursu ma wspólne potrzeby oraz cele, w tym wypadku zawodowe, co skutkuje wytworzeniem się grupy, która posiada „szczególną wiedzę specjalistyczną”, a co za tym idzie kompetencję ekspercką (Duszak 1998: 256).

Mówiąc o dyskursie naukowym, John Swales (1990) dokonał opisu tzw. wspólnoty dyskursywnej (tj. grupy skupionej na realizacji celów komunikacyjnych). Ich realizacja przez członków wspólnoty odbywa się za pomocą gatunków (genre) mowy oraz przy użyciu specyficznej leksyki. Koncepcja Swalesa pozwala więc wyodrębnić wspólnotę dyskursywną, jaką są specjaliści z zakresu medycyny (zarówno personel wyższy, jak i niższy), a założone cele obejmują wymianę poglądów oraz doświadczeń naukowych, przy czym środkami komunikacji wewnątrzgrupowej są sympozja, konferencje oraz publikacje naukowe na arenie krajowej i międzynarodowej. Forma pisemna komunikacji wewnątrzgrupowej możliwa jest dzięki określonym genre’om (manuskrypty, monografie).

$\mathrm{Z}$ pojęciem dyskursu nierozerwalnie wiąże się analiza dyskursu, która jako dziedzina za cel obiera sobie przeanalizowanie cech danego gatunku, co skutkuje wykształceniem właściwej kompetencji, mającej zakotwiczenie w standardach oraz normach zdefiniowanych przez społeczność naukową (Donesch-Jeżo 2013). Skuteczna komunikacja w schemacie nadawca-odbiorca zależy m.in. od efektywnego zastosowania właściwych środków lingwistyczno-retorycznych, które są typowe dla środowiska naukowego, rozumianego w niniejszym artykule jako społeczność osadzona w kontekście medycznym (Donesch-Jeżo 2013: 31). Obok kwestii werbalnych pod uwagę należy wziąć również kwestie wokalne, rozumiane jako intonacja, natężenie głosu, oraz kwestie niewerbalne (język ciała, mimika). Skuteczna komunikacja będzie się więc odbywała w sytuacji, gdy odbiorca właściwie zrekonstruuje znaczenie, które zostało przekazane mu przez nadawcę. 
Jest oczywiste, że z komunikacją specjalistyczną wiąże się posiadanie właściwej wiedzy językowej, a także znajomość norm funkcjonowania w relacjach międzyludzkich. Tłumacz musi mieć świadomość, iż w ramach medycyny występuje ponad 40 specjalizacji, co jest istotną liczbą z uwagi na to, że każda specjalizacja wykształciła dodatkowo odrębną terminologię (np. psychoonkologia, ginekologia onkologiczna). Związane jest to $\mathrm{z}$ rozwojem naukowym kadry, mającej w tym zakresie szereg możliwości, z których samoedukacja, szkolenia, wymiana doświadczeń konferencyjnych na arenie krajowej lub międzynarodowej stanowią zaledwie ułamek tego, czym kadra ta dysponuje w celu rozwijania kompetencji specjalistycznych. W każdej z tych sytuacji mamy do czynienia z komunikacją specjalistyczną.

Wielu badaczy podejmowało badania nad dyskursem medycznym czy też językiem specjalistycznym z różnych perspektyw (van Naerssen 1985; Steward 1995; Atkinson 1999; Kokot 2001; Wysocka 2001; Kościałkowska-Okońska 2012; Gotti 2016; Karwacka 2016; Bączkowska 2018).

W przypadku tłumacza medycznego istotną rolę powinna odgrywać świadomość w zakresie komunikacji na różnych płaszczyznach, z których pierwszą jest relacja specjalista-specjalista (użycie wiedzy wysokospecjalistycznej przy użyciu wysokospecjalistycznych leksemów oraz kolokacji), drugą - specjalista-niespecjalista (język specjalistyczny wraz z wyjaśnieniem terminów wysokospecjalistycznych), a trzecią - specjalista-laik (wytłumaczenie wiedzy specjalistycznej za pośrednictwem doboru środków z języka ogólnego przy pominięciu terminów specjalistycznych) (por. Wysocka 2001).

Pierwsza $\mathrm{z}$ płaszczyzn $\mathrm{w}$ dyskursie medycznym związana jest $\mathrm{z}$ porozumiewaniem się uczestników procesu komunikacyjnego w ramach relacji ekspert-ekspert/eksperci-eksperci, gdzie następuje wyznaczenie konkretnych algorytmów postępowania za pomocą norm i wytycznych, które zostają przekazane innym klinicystom w celu wdrożenia ich w odpowiednie postępowanie terapeutyczno-diagnostyczne. Nadawcą normy pozostaje panel ekspertów lub komisja wyznaczająca poszczególne kryteria. Za istotę takiego dyskursu można więc uznać przekazanie wytycznych adresatom pośrednim (tj. klinicystom), tak aby wdrożyli je u pacjentów (adresatów docelowych) w praktyce klinicznej. W zależności od tego, czy dane informacje będą dalej przekazywane pacjentom, czy też pozostaną w komunikacji wewnątrzspecjalistycznej, klinicyści stają się albo adresatami docelowymi, albo pośrednimi. Dyskurs naukowy w zakresie komunikacji między klinicystami jest wysokospecjalistyczny i skierowany wyłącznie do wybranych odbiorców w wysoko sformalizowanej formie wynikającej z jego specyfiki. Z uwagi na fakt, że kod, jakim posługują się zarówno nadawca, jak i odbiorca, jest ten sam, dystans 
między nimi ulega zmniejszeniu. Komunikacja wewnątrznaukowa rozumiana jest $\mathrm{w}$ tym przypadku jako kontakt pomiędzy specjalistami z zakresu jednego obszaru wiedzy. Gwałtowny rozwój medycyny, zwłaszcza procedur inwazyjnych (kardio- i neurochirurgii, chirurgii naczyń), skutkuje coraz większą proliferacją terminologiczną, szczególnie w zakresie pojedynczych leksemów, ale również kolokacji, zwłaszcza przymiotnikowych (Badziński 2018). Słowniki siłą rzeczy nie są i nigdy nie będą w stanie nadążyć za (nad) produkcją terminologii w omawianym zakresie, a koronnym przykładem jest medycyna nuklearna czy też neurochirurgia wraz ze wszystkimi kolokacjami związanymi z wysoce inwazyjnymi procedurami z zakresu badań obrazowych - pozytonowej tomografii emisyjnej oraz rezonansu magnetycznego (fistulografia MR, angiografia tętnic szyjnych, cholangiografia MR). W tym wypadku, mówiąc o języku specjalistycznym medycznym, mamy na myśli sytuację, w której adresatem oraz nadawcą jest wyższy lub średni personel medyczny.

W zakresie drugiej płaszczyzny (specjalista-niespecjalista) komunikacja może dotyczyć sytuacji przekładu, kiedy to tłumaczowi (niespecjaliście) należy udzielić informacji specjalistycznej z danej dziedziny (informacja zwrotna od specjalisty), aby rozumiejąc język nadawcy, tłumacz mógł poprawnie przełożyć komunikat na język docelowy, samemu nie będąc specjalistą w danym zakresie.

Należy jednak mieć na uwadze fakt, że komunikacja w domenie medycznej nie musi odbywać się wyłącznie pomiędzy specjalistami w danej dziedzinie (płaszczyzna pierwsza) lub pomiędzy specjalistą a niespecjalistą (płaszczyzna druga), gdyż tekst może być uproszczony i dostosowany do odbiorcy, który w ogóle nie posiada wykształcenia medycznego (diabetycy informowani o konieczności pomiarów poposiłkowego stężenia glikemii). Wówczas komunikacja przebiega wertykalnie (relacja lekarz-pacjent). W tym zakresie specjalista powinien wyjaśnić wiedzę specjalistyczną przy użyciu terminologii z języka ogólnego w możliwie najprostszy sposób, aby pacjent był w stanie poprawnie zrozumieć przekaz. Dla zilustrowania: wysokospecjalistyczne kolokacje $\mathrm{z}$ dziedziny hepatologii aminotransferaza/transaminaza asparaginianowa czy też aminotrasferaza/transaminaza alaninowa powinny być uproszczone do formy badania prób wątrobowych. Użycie innej, nawet uproszczonej formy (włączając w to akronimy powyższych kolokacji - AspAt czy ALAT) nie rozwiązuje sytuacji, gdyż terminy te nadal pozostają niejasne. Co więcej, tłumacz powinien wiedzieć, który z leksemów (aminotransferaza/transaminaza) jest typowy dla danej dziedziny. Ponadto lekarze powinni wykazywać się wysokim stopniem świadomości w zakresie użycia odpowiednich lekse- 
mów zależnie od interlokutora (innego specjalisty czy też pacjenta laika). W innym przypadku możemy mówić o niezamierzonych błędach w komunikacji, które mogą dodatkowo komplikować sytuację - pacjent nieznający nomenklatury medycznej najprawdopodobniej zareaguje panicznie na informację, że ma zdiagnozowany nowotwór, nie będąc świadomym, iż nowotwory mogą być łagodnymi zmianami i niekoniecznie muszą ulegać konwersji (zezłośliwieniu), w związku z czym nie powinny niepokoić pacjenta. Jednak w sytuacji nieświadomości terminologicznej powyższa diagnoza może być szokiem dla pacjenta $\mathrm{z}$ racji błędnej formy zastosowanej przez nadawcę wobec adresata (mimo najszczerszych intencji).

Deborah Tannen i Cynthia Wallat (1993) przeprowadziły interesujące badanie, w którym dokonały analizy procesu komunikacji z udziałem strony trzeciej (tj. rodzica). Przeprowadzone na oddziale pediatrii badanie wykazało złożoność potrzeb emocjonalnych względem lekarza spowodowaną zaangażowaniem rodziców w badanie fizykalne dziecka. Szczególną uwagę zwrócono na nieporozumienia wynikające $\mathrm{z}$ wyboru sformułowań lub nawet intonacji stron zaangażowanych $\mathrm{w}$ proces komunikacji. $\mathrm{Z}$ kolei wydaje się, że kluczowe znaczenie dla omawianego problemu ma badanie Candace West (1990), ponieważ wskazało, w jaki sposób lekarze w zależności od płci formułowali swoje wytyczne względem pacjentów, a także jakie były reakcje pacjentów. Analiza West wykazała, że lekarze w zależności od płci wydawali polecenia w całkowicie odmienny sposób, co znacząco wpłynęło na reakcje pacjentów. Lekarze stosowali jasne i nieznoszące sprzeciwu formy wypowiedzi, które podkreślały (a nawet pogłębiały) różnice między nimi a pacjentami i tym samym jeszcze bardziej uwidaczniały przepaść w relacjach lekarz-pacjent (hierarchizacja wertykalna). Z drugiej strony, lekarki minimalizowały takie różnice, co wskazuje na wysoce asymetryczny rozkład wypowiedzi w zależności od płci, a także związek między płcią a perswazją lekarzy wobec pacjentów.

Pewne novum dla tłumacza stanowi telemedycyna (w ramach wszystkich trzech wyżej opisanych płaszczyzn), co niewątpliwie związane jest $\mathrm{z}$ wszechobecnym postępem technologicznym. Ta pionierska i zarazem coraz szerzej implementowana forma komunikacji, zwłaszcza w ośrodkach z trzecim stopniem referencyjności, wymaga od tłumacza kompetencji w zakresie przekładu zarówno pisemnego, jak i ustnego (często w trybie symultanicznym). Wprowadzona pod koniec lat 60. XX wieku, stała się obecnie nowatorską formą komunikacji oraz zyskała międzynarodowe uznanie, szczególnie od 2001 roku, po części dzięki postępom w technologii inwazyjnych procedur (śródoperacyjna biopsja FNA), a zwłaszcza w badaniach obrazowych (tomografia 
komputerowa stożkowa, obrazowanie metodą MRI w ramach pojedynczej akwizycji). Tego typu komunikacja stała się osiągalna dzięki implementacji połączenia internetowego. Wideokonferencje, tłumaczenia symultaniczne oraz konsekutywne, telediagnostyka, teleopieka oraz teleedukacja czy też zdalne wykonywanie procedur chirurgicznych zajmują szczególną pozycję $\mathrm{w}$ tym zakresie (zabieg $\mathrm{w}$ czasie rzeczywistym $\mathrm{z}$ równoczasową rekonsultacją). Procedury te są stosowane na szeroką skalę w wielu krajach (USA, Norwegia, Japonia). Co więcej, stały się też złotym standardem w niektórych placówkach medycznych (Johns Hopkins University). Wobec powyższego, telemedycyna jako forma specjalistycznej komunikacji służy przekazywaniu i rozszerzaniu specjalistycznej wiedzy na arenie międzynarodowej, co pociąga za sobą również konieczność edukacji tłumaczy ustnych.

Język stanowi podstawowe narzędzie dyskursu naukowego, w którym nadrzędną staje się funkcja informacyjna. Postęp w naukach medycznych byłby niemożliwy przy braku prawidłowej wymiany informacji czy też komunikacji wewnątrzspecjalistycznej (seminaria, sympozja, konferencje, artykuły pokonferencyjne, prace poglądowe). Dodatkowo, rozwój w ramach jednej specjalizacji przekłada się na postęp w ramach innych specjalizacji, a czasem skutkuje powstaniem nowej (np. ginekologia onkologiczna). Specjalistyczna komunikacja $\mathrm{w}$ dyskursie medycznym służy więc wymianie doświadczeń, prezentacji własnych dokonań, ale również otrzymywaniu informacji zwrotnej oraz algorytmów postępowania. Zawrotny postęp skutkuje wyłonieniem się specjalistów, którzy wykształcili się w ramach wąskiej specjalizacji i stali się grupą niemal hermetyczną z uwagi na język specjalistyczny, którym się posługują.

\section{Języki specjalistyczne i ich charakterystyka}

Język stanowi narzędzie dyskursu, a języki specjalistyczne stały się przedmiotem znacznego zainteresowania dopiero w XX wieku (Gajda 2001). Zdaniem Marii Piotrowskiej (2007) w Polsce w ostatnim czasie znacznie rośnie zainteresowanie językami specjalistycznymi. Definiuje je ona jako szczególną postać języka ogólnonarodowego, która jest przystosowana do precyzyjnego opisu określonej gałęzi wiedzy, a od języka ogólnego różni się głównie słownictwem fachowym, składnią oraz częstotliwością użycia poszczególnych form gramatycznych.

Język medyczny wpisuje się do grupy tzw. technolektów/profesjolektów (języków specjalistycznych zawodowych), jakimi posługują się osoby nale- 
żące do danej grupy. Termin język specjalistyczny (funkcjonalny) występuje w literaturze obcojęzycznej pod różnymi nazwami: scientific (technical) language, special/functional language (j. angielski), Fachsprache (j. niemiecki), langue spéciale (j. francuski) (Pieńkos 1999). Trudno precyzyjnie określić moment, w którym język ogólny staje się funkcjonalnym (Radziszewska 2012) i odwrotnie. Jest to zgodne z obserwacjami Sambora Gruczy (2009), który podkreśla, że termin obecnie wchodzący w skład technolektu wkrótce może już być elementem języka ogólnego. Zjawisko to jest szczególnie dobrze uwidocznione w zakresie jednostek chorobowych oraz (nie)inwazyjnych procedur (np. rezonans magnetyczny z podaniem środka kontrastowego lub bez niego). Ponadto technolekt danej specjalizacji medycznej może zawierać dodatkowo elementy technolektu charakterystyczne dla innych specjalizacji (alergologia zawierająca informacje z immunologii klinicznej czy badań molekularnych).

Cechą charakterystyczną języka specjalistycznego jest więc operowanie terminologią, która nie doprowadza do polisemii (dwuznaczności), a funkcjami podstawowymi tego języka pozostają funkcje informacyjne, poznawcze oraz komunikacyjne; terminy naukowe są mniej znane ogółowi społeczeństwa, ponieważ ich użycie odbywa się w domenie specjalistycznej. Poza tym, jak podaje Jerzy Pieńkos (1999), użycie wysokospecjalistycznej oraz fachowej terminologii (dostępnej wyłącznie wtajemniczonym) jest potwierdzeniem tożsamości zawodowej, stając się niejako testem tego, czy dana osoba należy do grona ekspertów (specjalistów), czy też nie.

Typologia języka medycznego, obok tzw. języka medycznego praktycznego (epikryzy, skierowania), wyróżnia także specjalistyczny język medyczny naukowy, który podlega dalszemu podziałowi na język praktyczny-naukowy (wytyczne oraz rekomendacje stowarzyszeń), informacyjno-naukowy (manuskrypty, prace zjazdowe) oraz popularnonaukowy (informacje dostępne dla niespecjalistów). Dodatkowo Piotr Mamet i Grzegorz Gwóźdź (2015) słusznie postulują, że praktyczna kwestia dyskursów specjalistycznych jest związana z kwestią dydaktyki języka specjalistycznego oraz tworzenia warsztatu tłumacza, który zajmuje się dyskursami specjalistycznymi.

Jak słusznie zauważa Agnieszka Sawicka (2009), wspólne cechy języków klinicystów (idiotechnolektów) noszą nazwę politechnolektów. W dużo większym więc stopniu można mówić o pokrywaniu się idiotechnolektów poszczególnych użytkowników języka specjalistycznego w ramach tej samej dziedziny (radiologia, onkologia, genetyka) niż w ramach całej nauki, jaką jest medycyna. Należy pamiętać, że technolekty różnych użytkowników języka specjalistycznego nie są i nie będą w pełnej korelacji względem siebie 
w zakresie pełnej synonimiczności z racji rozbieżności w zakresie wiedzy specjalistycznej poszczególnych klinicystów, niezależnie od rodzaju specjalizacji. Nie istnieją również obiektywne miary, które mogłyby ocenić stopień wyspecjalizowania się nawet w obszarze jednej specjalizacji. Dlatego też z definicji należy oczekiwać różnic w omawianym zakresie. W wypadku nowo tworzonych specjalizacji (hipertensjologia, nanomedycyna) idiotechnolekty będą miały znacznie mniej elementów wspólnych, więc politechnolekt w tych domenach medycyny będzie (siłą rzeczy) uboższy względem innych, dłużej istniejących specjalizacji (chirurgia naczyniowa). Dodatkowo na uwagę zasługuje fakt, że w miarę rozwoju specjalizacji nowe leksemy oraz kolokacje są sukcesywnie wprowadzane do użytku.

Język ogólny stanowi bazę wyjściową dla technolektu, który opiera się zarówno na gramatyce języka ogólnego, jak i jego fonologii i fonetyce (cechach charakterystycznych danego języka w zakresie dźwięków mowy), ale jego celem pozostaje przekaz wiedzy z dziedzin specjalistycznych (Grucza 2009). W przeciwieństwie do języka ogólnego żaden język specjalistyczny nie jest samodzielny, gdyż używa zarówno leksykonu języka ogólnego, jak i terminologii specjalistycznej z danej dziedziny. W związku z powyższym Sawicka (2009) podaje szereg różnic pomiędzy językiem ogólnym a specjalistycznym na wielu płaszczyznach. Wśród tych najbardziej istotnych należy wymienić: morfologię, składnię, słownictwo, semantykę i ich funkcje. Zdaniem Urszuli Żydek-Bednarczuk (2001: 32), „na obraz języka specjalistycznego należy popatrzeć z perspektywy doboru środków językowych, uwarunkowanych funkcjami, jakie spełnia ta odmiana języka w kontaktach między członkami określonych grup społeczno-zawodowych". Zatem różnorodność występuje nie w warstwie gramatycznej, lecz w odpowiedniej selekcji poszczególnych leksemów z poziomu morfologicznego. Według Żydek-Bednarczuk fonologiczno-syntaktyczny system nie wykazuje różnic względem tego, który jest zaadaptowany na potrzeby języka ogólnego, a charakterystyka wyraża się właśnie w zakresie semantycznym, co jest skorelowane z teorią referencyjności, która w szczególności zwraca uwagę na wyodrębnienie poszczególnych leksemów.

W kategorii funkcji język ogólny może posługiwać się m.in. funkcją ekspresywną, poetycką, fatyczną, konatywną, podczas gdy nadrzędną funkcją języka specjalistycznego (medycznego) jest funkcja informatywna, zwłaszcza w wypadku algorytmów postępowania terapeutycznego. Na poziomie syntaktycznym zdania wielokrotnie złożone są dominantą języka medycznego wraz z obecnością konstrukcji bezosobowych czy wtrąconych oraz wysoką częstością grup nominalnych, nadających wypowiedzi charakter formalny, 
którym często towarzyszy strona bierna celem podkreślenia nadrzędności czynności lub (nie)inwazyjnej procedury (Gajda 2001). W semantyce języka medycznego występuje monosemia (jednoznaczność), podczas gdy w języku ogólnym polisemia (Pieńkos 1999). Rzeczowość, precyzja i brak nacechowania emocjonalnego są typowymi cechami języka medycznego, w odróżnieniu od języka ogólnego, w którym brak precyzji przekazu, a elementy subiektywno-emocjonalne są widoczne. W warstwie słowotwórczej nowe słowa w języku ojczystym są tworzone najczęściej zgodnie ze standardowymi technikami słowotwórczymi, rzadziej jako zapożyczenia, w przeciwieństwie do języka medycznego, w którym zapożyczenia z innych języków (w szczególności z języka angielskiego i dawniej łaciny i/lub greki) stanowią statystycznie istotny odsetek terminologiczny.

Słownictwo nadal pozostaje prawdopodobnie najbardziej problematyczną cechą języka medycznego, zarówno w komunikacji, jak i w przekładzie, co niejako wyznacza granicę podziału języków na ogólny oraz specjalistyczny. Tendencja do nowotworzenia (rozumianego w tym przypadku jako proliferacja jednostek terminologicznych) jest wyjątkowo częsta. Gajda (2001) podkreśla znaczenie nie tyle leksemu, co łączenia słów w skupienia terminologiczne (kolokacje), które są najbardziej produktywnym obecnie sposobem tworzenia terminów - 80-90\% nazw stanowią tego typu połączenia $\mathrm{w}$ terminologii formalnej. Co ciekawe, badania nad tekstem specjalistycznym przez wiele lat były ograniczone wyłącznie do poziomu leksemów, co uległo zmianie wraz z nadejściem lingwistyki tekstu, która w swoim obszarze badań ciężar gatunkowy przeniosła na większe jednostki (Kozłowska 2007).

Wioletta Mela (2012) zwraca uwagę na łańcuchy terminologiczne, gdyż w medycynie czy farmacji nader często występują skupiska pięcio- czy nawet sześciowyrazowe (ciężkie niepożądane działanie produktu leczniczego), a pod względem kategorii gramatycznej najczęstszym terminem jest właśnie rzeczownik. Według Meli (2012), w dziedzinie farmacji obserwowana jest przewaga liczebna wielokomponentowych jednostek terminologicznych względem terminów dwu- lub trzywyrazowych, co również sygnalizuje Włodzimierz Lejczyk (1998) i podkreśla, że wśród jednostek stanowiących tzw. łańcuchy terminologiczne (kolokacje) najbardziej produktywną grupą pozostaje układ trzech wyrazów, szczególnie rzeczownik-rzeczownik-przymiotnik (import produktów leczniczych), bądź też imiesłów przymiotnikowy-rzeczownik-przymiotnik (badany produkt leczniczy). Dzieje się tak za sprawą nominalizacji, dzięki której możliwy jest transfer dużej ilości informacji merytorycznej. Dodatkowo nomenklatura specjalistyczna funkcjonuje na kilku poziomach, tym samym charakteryzując się różnym stopniem specjalizacji. 
W związku z powyższym należałoby dokonać usystematyzowania leksemów i kolokacji o różnym stopniu zawiłości terminologicznej na te bardziej podstawowe oraz takie o wyjątkowo wysokim stopniu specjalizacji. Następnie taką typologię można by zaimplementować w dydaktyce przekładu, gdyż to właśnie kolokacje należą do najtrudniejszych wyzwań, z jakimi muszą zmagać się tłumacze tekstów medycznych (Badziński 2018).

\section{Metafora, metonimia i eponimia w języku medycznym}

Wśród uwag dla tłumacza dotyczących języka medycznego należy zasygnalizować stosunkowo częste zjawisko występowania metafor. Analiza artykułów naukowych jasno pokazuje, że pojęcie metafory jest nie tylko obecne w relacji pacjent-lekarz w celu klaryfikacji zagadnień, które nie są jasne dla pacjenta, ale ich obecność jest również wyraźnie zaznaczona w tekstach wysokospecjalistycznych, co może stanowić dobry materiał badawczy. Metafora występuje we wszystkich językach, a co za tym idzie, również w językach specjalistycznych. Nie jest wyłącznie kwestią językową, ponieważ procesy myślowe same w sobie są często metaforyczne, a istnienie metafor jako wyrażeń lingwistycznych jest możliwe, ponieważ występują one w ludzkim systemie konceptualnym (Lakoff i Johnson 1980). Mamet oraz Gwóźdź (2015) podkreślają, że metafora jest obecna w specjalistycznym dyskursie oraz $\mathrm{w}$ jego analizie, trudno zatem znaleźć część ciała, której nie zostałoby przypisane znaczenie metaforyczne.

Wśród metafor najczęściej pojawia się motyw militarystyczny - opis układu immunologicznego gospodarza jako armia, podejmująca obronę. W badaniu Davida Casaretta (2010) tego typu metafory pojawiały się aż 42 razy, co jest istotnie statystyczną wartością. Szczególnie jest to widoczne w onkologii w trakcie radio- i/lub chemioterapii. Casarett wyjaśnia, że metafory pojawiają się zarówno w języku naukowym, jak i w rozmowie z pacjentem. Niezależnie od tego, czy zjawisko omawiane jest z perspektywy języka polskiego, czy angielskiego, receptory opisywane są na zasadzie włącznika-wyłącznika (on-off), choroba jest wrogiem, a komórki NK to naturalni zabójcy, podobnie zresztą jak inne limfocyty, które mają za zadanie zabić komórki nowotworowe. Ponadto leczenie jest agresywne, a walka komórek układu immunologicznego z rakiem może być wygrana lub przegrana. Zmienione nowotworowo komórki (czyli guzy złośliwe), które dokonały inwazji danego organu, są bombardowane przy użyciu radioterapii czy brachyterapii, a te same komórki, które nie poddały się agresywnemu działaniu tej procedury inwa- 
zyjnej, mogą z czasem uwidocznić się w formie przerzutów - tak więc celem wojny $\mathrm{z}$ rakiem pozostaje batalia o życie i zdrowie pacjenta, a także zapobieżenie dalszej inwazji komórek złośliwych na zdrową tkankę. Paul Hodgkin (1985) również potwierdza, że metaforą najczęściej stosowaną w medycynie pozostaje wojna. W dyskursie medycznym metafora jest tak bardzo skonwencjonalizowana, że praktycznie nie da się odnieść do choroby oraz leczenia bez odniesień do metaforyki dotyczącej wojny (Hillmer 2007). Typowymi przykładami są więc następujące metafory: CHOROBA TO PODEJRZANY, DIAGNOZA TO WYROK (culprit coronary artery, symptom responsible for); MEDYCYNA TO WOJNA, CHOROBA TO WRÓG - (flare-up of lupus, battle suicidal thoughts, fight viral epidemics, combat affective disorder, invasion of pathogens). Casarett (2010) dodatkowo wykazal, że lekarze używają metafor $\mathrm{w}$ ponad $2 / 3$ rozmów z pacjentami. Jednakże metafory występują również w artykułach o wysokim wskaźniku Impact Factor. Różnorodność domen docelowych, a także ich bogactwo wskazują, że są one wyjątkowo istotną składową dyskursu medycznego. Badania nad metaforą $\mathrm{w}$ języku medycznym pokazują więc, iż jest ona wszechobecna, co tym bardziej powinno skłonić tłumacza do wnikliwej analizy tekstu źródłowego w celu oddania danej metafory, najczęściej wyrażonej w formie kolokacji.

Kolejnym przykładem tworzenia kolokacji w dyskursie medycznym jest metonimia, która często pojawia się w tekstach (popularno)naukowych. Błędna pod względem logicznym fraza zmarł na AIDS to klasyczny przykład metonimii (w rzeczywistości ludzki wirus upośledzenia odporności nie skutkuje zgonem, jednak osłabia układ immunologiczny do takiego stopnia, że zgon następuje z przyczyn związanych z AIDS, czyli w praktyce z powodu jakiejkolwiek innej choroby). Metonimia często dotyczy substancji czynnych oraz procedur (podać sertralinę, przepisać metronidazol, zlecenie na TK). Należy pamiętać, że $\mathrm{w}$ takich przypadkach nie zawsze będziemy mieli do czynienia z pełną ekwiwalencją. Na przykład wykonać próby wątrobowe (do liver function test) jest dwuznaczne. Wyrażenie to może oznaczać zarówno pomiar aminotransferazy asparaginianowej, transaminazy alaninowej oraz bilirubiny, GGTP czy też fosfatazy alkalicznej, podczas gdy w krajach anglosaskich (zależnie od ośrodka) panel prób wątrobowych bardzo często dotyczy wyłącznie dwóch pierwszych transaminaz. Tłumacz więc powinien być świadomy takich różnic.

Eponimia to kolejne wyzwanie dla tłumacza, które polega na transpozycji nazwiska danej osoby na odkrycie, teorię czy też prawo, którego dana osoba była twórcą (Perlińska 2009). Pomimo jej mnogości w tekstach medycznych (ponad 13 000), od 2000 roku obserwowany jest trend malejący w kwestii 
ich użycia przy jednoczesnym zastępowaniu eponimów innymi leksemami. Dla zilustrowania: eponim choroba Hallervordena-Spatza (manifestacja kliniczna zaburzeń spichrzania żelaza) jest obecnie unikany z powodu bliskiej współpracy zarówno Spatza oraz Hallervordena z nazistami, a w niektórych krajach eponim ten jest obecnie niedopuszczalny w nomenklaturze medycznej. Co więcej, odczyn Biernackiego nie ma ekwiwalentu w języku angielskim jako eponim, ponieważ w krajach anglosaskich polski uczony nie był znany, a na omawiane zjawisko używa się formy deskryptywnej erythrocyte sedimentation rate (ESR), co koreluje znaczeniowo $\mathrm{z}$ polskim odpowiednikiem (wskaźnik opadania krwinek czerwonych), podobnie jak choroba Leśniowskiego-Crohna (w j. ang. tylko Crohn disease). Problemy pojawiają się również w sytuacji tłumaczenia rzeczowników pospolitych (O’Connor scope to nie $z a$ kres O'Connora, ale wziernik O'Connora). Czasami dane schorzenie ma kilka odpowiedników w języku angielskim (Graves-Basedow disease i Parry disease), jednak w języku polskim odpowiada jej jeden termin - choroba Gravesa-Basedowa. Co więcej, Luy body to ciało Luysa, podczas gdy Paschen body to nie ciało, ale ciałko Paschena, gdyż odnosi się do ciałek wtrętowych. Kahler disease to eponim, który jest wyjątkowo zwodniczy - odnosi się bowiem do dwóch zupełnie różnych jednostek chorobowych - szpiczaka mnogiego lub wielokorzonkowego zapalenia kiłowego z niedowładem wiotkim kończyn. Dobry tłumacz tekstów medycznych powinien więc wykazać się niezwykłą uważnością w kwestii doboru ekwiwalentu, szczególnie w przypadku eponimów.

\section{Podsumowanie}

Reasumując, pojęcie dyskursu i jego analiza mogą być problematyczne ze względu na mnogość definicji, które je określają, oraz różnorodność zastosowanych metodologii badań. Skuteczna komunikacja jest jednak warunkiem sine qua non przekazu wiadomości i wiedzy, której celem jest zapewnienie pacjentom opieki na najwyższym poziomie zgodnie z zasadami medycyny opartej na dowodach. Warunkiem skutecznej komunikacji i procesu przekładu jest zaangażowanie wszystkich stron oraz precyzja w zapewnieniu odpowiedniej wymiany informacji, której brak może blokować przepływ informacji, a nawet skutkować stanami zagrożenia życia. Zjawisko dyskursu medycznego pozostaje kwestią kluczową w przekładzie pisemnym oraz ustnym, gdyż nieznajomość reguł rządzących dyskursem uniemożliwia prawidłowy przekład specjalistyczny, stąd też dyskurs oraz zjawiska z nim związa- 
ne bezpośrednio przekładają się na proces przekładu specjalistycznego oraz dydaktykę przekładu języka specjalistycznego, który to język funkcjonuje sprawnie wyłącznie w sytuacji, kiedy obydwie strony (nadawca-odbiorca) używają tego samego kodu i pragną osiągnąć wspólny cel. Różnice między językiem ogólnym a specjalistycznym są natury ilościowej, a nie jakościowej (takie same komponenty i struktury gramatyczne, jednak z różną proporcją ilościową). Dyskurs medyczny, jako sposób użycia języka w określonych kontekstach medycznych, jest związany z gatunkami, które są usystematyzowane w zależności od sytuacji lub uczestników dyskursu. Z kolei analiza dyskursu pozwala na zrozumienie cech konkretnego genre'u, co w konsekwencji powoduje powstawanie tekstów $\mathrm{z}$ danej specjalności medycznej. W sytuacji pogwałcenia zasad związanych z tworzeniem tekstu wyniki badań, jak i same publikacje mogą zostać odrzucone lub nawet zdyskredytowane. Jak wykazano powyżej, z punktu widzenia dydaktyki przekładu dyskurs medyczny zapewnia również szereg możliwości i zasobów, które można wykorzystać nie tylko w przypadku młodych adeptów tłumaczenia.

Powyższa charakterystyka kluczowych zagadnień przekładu medycznego powinna skłonić tłumaczy do dogłębnej analizy tekstu. Tłumacz musi mieć świadomość złożoności merytorycznej tłumaczonych zjawisk. Obecnie dydaktyka tłumaczy medycznych powinna skupić się na powyższych składowych, które stanowią podstawę procesu prawidłowego przekładu, a które często (błędnie) brane są za oczywistość, co skutkuje czasem konsekwencjami utraty życia, co zaobserwował autor powołany jako ekspert sądowy do oceny błędów tłumaczeniowych innego tłumacza, które przyczyniły się w konsekwencji do śmierci pacjenta poddanego procedurze chirurgicznej.

\section{Wnioski końcowe}

Tłumacz medyczny musi mieć świadomość kluczowego znaczenia nie tylko leksemu, ale również osadzenia go w odpowiedniej kolokacji. Wymagane są zatem dalsze badania $\mathrm{z}$ zakresu analizy dyskursu medycznego, języka medycznego, jego dydaktyki oraz kolokacji medycznych w celu szerszego zrozumienia problematyki, a tym samym wypracowania (być może) jednego modelu, według którego można by dokonać charakterystyki omawianych zjawisk, tym razem względem poszczególnych specjalizacji medycznych, co mogłoby ukazać ciekawe zależności, podobieństwa i różnice w doborze zarówno ekwiwalentów kolokacyjnych, jak i innych składowych przy zachowaniu precyzji przekładu. Takiej wymianie informacji musi przyświecać zawsze pod- 
stawowa maksyma łacińska primum non nocere, która powinna być składową w dyskursie medycznym, w przekładzie oraz jego dydaktyce, a dla tłumacza powinna być fundamentalną zasadą.

\section{Literatura}

Atkinson P., 1999, Medical discourse, evidentiality and the construction of personal responsibility, [w:] Talk, work, and institutional order: Discourse in medical, mediation, and management settings, S. Sanagri, C. Roberts (red.), Berlin-New York, s. 75-108.

Bachtin M., 1986, Estetyka twórczości słownej, Warszawa.

Badziński A., 2018, Collocations, Equivalence and Untranslatability as selected critical aspects in medical translation, [w:] Towards Understanding Medical Translation and Interpreting, W. Karwacka (red.), Gdańsk, s. 67-84.

Ballard K., 2016, The Stories of Linguistics. An Introduction to Language Study. Past and Present, London.

Bączkowska A., 2018, Functional analysis of lexical bundles in medical discourse, „Conversatoria Linguistica”, XII, s. 7-25.

Casarett D., Pickard A., Fishman J., Alexander S., Arnold R., Pollak K., Tulsky J., 2010, Can Metaphors and Analogies Improve Communication with Seriously Ill Patients?, „Journal of Palliative Medicine”, 13(3), s. 255-260. Donesch-Jeżo E., 2013, Akademicki dyskurs medyczny w języku angielskim i polskim w ujęciu lingwistycznym i metodycznym: artykuł naukowy i jego abstrakt, Kraków.

Duszak A., 1998, Tekst, dyskurs, komunikacja międzykulturowa, Warszawa. Gajda S., 2001, Polskie języki specjalistyczne dawniej i dziś, [w:] Języki specjalistyczne. Język biznesu, J. Arabski (red.), Katowice, s. 7-24.

Gotti M., 2016, Variations in Medical Discourse for Academic Purposes, [w:] Medical Discourse in Professional, Academic and Popular Settings, P. Ordonez-Lopez, N. Edo-Marza (red.), Bristol-Buffalo-Toronto, s. 9-30.

Grucza S., 2009, Kategoryzacja języków (specjalistycznych) w świetle antropocentrycznej teorii języków ludzkich, „Komunikacja Specjalistyczna”, 2, s. $15-30$.

Hillmer I., 2007, The way we think about diseases: "the immune defense" comparing illness to war, „NAWA Journal of Language and Communication", 1(1), s. 22-30.

Hodgkin P., 1985, Medicine is war: and other medical metaphors, „British Medical Journal", 291(6511), s. 1820-1821. 
Karwacka W., 2016, Przekład tekstów medycznych, Gdańsk.

Kiklewicz A., 2015, Kategoryzacja dyskursu, [w:] Dyskurs: aspekty lingwistyczne, semiotyczne i komunikacyjne, A. Kiklewicz, I. Uchwanowa-Szmygowa (red.), Olsztyn, s. 15-41.

Kokot U., 2001, Metody przekładu niemieckich nazw medycznych na język polski, Katowice.

Kościałkowska-Okońska E., 2012, Translating medical texts for legal purposes: A growing challenge for court translators and interpreters, „Comparative Legilinguistics", 11, s. 7-21.

Kozłowska Z., 2007, O przekładzie tekstu naukowego (na materiale tekstów językoznawczych), Warszawa.

Lakoff G., Johnson M., 1980, Metaphors We Live By, Chicago.

Laskowska E., 2004, Dyskurs parlamentarny w ujęciu komunikacyjnym, Bydgoszcz.

Lejczyk W. M., Biesiekirska L., 1998, Terminoznawstwo: przedmiot, metody, struktura, Białystok.

Mamet P., Gwóźdź G., 2015, Dyskursy specjalistyczne, Częstochowa.

Mela W., 2012, Polskie słownictwo prawa farmaceutycznego jako przedmiot konstruowania terminologicznego, „Komunikacja specjalistyczna”, 5, s. 33-39.

Noińska M., 2017, O źródłach wieloznaczności pojęcia dyskurs w językoznawstwie (na materiale języków polskiego, rosyjskiego i angielskiego), „Progress. Journal of Young Researchers”, 2, s. 72-82.

Perlińska L., Krzyżowski J., 2009, Medical eponyms. Leksykon, Warszawa.

Pieńkos J., 1999, Przekład i tłumacz we współczesnym świecie, Warszawa.

Piotrowska M., 2007, Proces decyzyjny tłumacza, Kraków.

Radziszewska A., 2012, Strategie translatorskie w przekładzie terminologii z dziedziny zarządzania, Kraków.

Sawicka A., 2009, Krótka charakterystyka języków specjalistycznych, „Komunikacja Specjalistyczna", 2, s. 188-198.

Steward M., 1995, Effective physician-patient communication and health outcomes: a review, „Canadian Medical Association Journal”, 152(9), s. $1423-1433$.

Swales J. M., 1990, Genre analysis. English in academic and research settings, Cambridge.

Szacki J., 2005, Historia myśli socjologicznej, Warszawa.

Tannen D., Wallat C., 1993, Doctor/mother/child communication: Linguistic analysis of a pediatric interaction, [w: The social organization of doctor-patient communication, A. D. Todd, S. Fisher (red.), Norwood, NJ, s. $31-48$. 
Van Dijk T., 2001, Dyskurs jako struktura i proces, Warszawa.

Van Naerssen M., 1985, Medical Records: One Variation of Physician's Language, „International Journal of the Sociology of Language”, 51, s. 43-73.

West C., 1990, Not just "doctors' orders": Directive-response sequences in patients' visits to women and men physicians, „Discourse \& Society”, 1(1), s. $85-112$.

Wojtak M., 2010, Dyskurs religijny w mediach. Próba rekonesansu, [w:] Dyskurs religijny w mediach, „Teolingwistyka” 8, D. Zdunkiewicz-Jedynak (red.), Tarnów, s. 7-30.

Wysocka M., 2001, Podkody angielszczyzny medycznej, [w:] Języki specjalistyczne. Język biznesu, J. Arabski (red.), Katowice, s. 118-121.

Żydek-Bednarczuk U., 2001, Rejestry języka specjalistycznego, [w:] Języki specjalistyczne. Język biznesu, J. Arabski (red.), Katowice, s. 27-41.

\section{Discourse in the domain of medical specialist language - remarks for translators and teachers of translation}

\section{Summary}

Medical discourse and its analysis remain problematic due to the multitude of related definitions and different approaches to the methodology of research. Additionally, ever-increasing proliferation of medical terms, various treatment modalities in accordance with the evidence-based medicine and a plethora of medical specialties may further complicate the process of communication and translation irrespective of the parties involved in these processes. Therefore highly effective translation and transfer of medical knowledge can be achieved provided that the parties involved in the process use the same code and wish to reach the common aim. The paper provides translators with theoretical and practical guidelines. It characterizes the language of medicine and discusses in detail the key aspects related to communication in translation, including collocations, precision, metonymy and metaphors in the domain of the specialized language. Bearing in mind the above, these issues should be included in the process of teaching medical translation and translators should always follow the maxim primum non nocere.

Keywords: medical discourse, language of medicine, medical collocations, medical translation, teaching medical language 